\title{
An effect-analysis method for species-dependent coral health status in temperature and ammonia: a case study of Acropora sp., Turbinaria sp., and Porites sp.
}

\author{
U Bussapakorn ${ }^{1}$, C Petchporn ${ }^{1}$ and R Sompop ${ }^{2}$ \\ ${ }^{1}$ Graduate student, Associate Professor, Department of Environmental Engineering, Chulalongkorn University, Bangkok 10330, \\ Thailand \\ ${ }^{2}$ Senior Researcher, Aquatic Resources Research Institute, Chulalongkorn University, Bangkok 10330, Thailand
}

\begin{abstract}
This research aimed to study the effects of temperature and ammonia on the health status of Acropora sp., Turbinaria $s p$., and Porites $s p$. by using acute toxicity testing (50\% Lethal Concentration: $\left.\mathrm{LC}_{50}\right)$. The acute effects were monitored at temperatures of $30^{\circ} \mathrm{C}$ and $33^{\circ} \mathrm{C}$ at 24 and $48 \mathrm{hrs}$. The concentrations of ammonia varied at 00.050 .07 and $0.1 \mathrm{mgN} / \mathrm{L}$, respectively. The active polyp percentages of Acropora $\mathrm{sp}$. was analyzed with comparison to the health status percentages. According to the findings at $30^{\circ} \mathrm{C}(24$ and $48 \mathrm{hrs})$ and $33^{\circ} \mathrm{C}(24 \mathrm{hrs})$, the $\mathrm{LC}_{50}$ could not be investigated because the mortality percentages was not below $50 \%$. On the other hand, at $33^{\circ} \mathrm{C}(48 \mathrm{hrs})$, the $\mathrm{LC}_{50}$ could be evaluated because the mortality percentages exceeded $50 \%$. Therefore, the $\mathrm{LC}_{50}$ at $48 \mathrm{hrs}$ of Acropora sp., Turbinaria sp., and Porites sp. were equal to $0.043,0.075$ and $0.054 \mathrm{mgN} / \mathrm{L}$, respectively.
\end{abstract}

\section{Introduction}

Corals are marine invertebrates that are classified in the phylum Cnidaria. Corals get food through suspension and autotrophic feeding on Zooxanthellae algea. Corals and Zooxanthellae share a mutual symbiosis, because algae accelerate the limestone formation process and coral hues. Corals grow well at water temperatures between $25-30^{\circ} \mathrm{C}[1]$. When marine environments have changed or conditions are unsuitable such as high seawater temperatures exceeding $30^{\circ} \mathrm{C}$ or drops in salinity [2] [3], algae produces substances that are toxic to coral tissues. Coral becomes stressed and will drive algae out from the coral tissues. This results in a loss in coral pigment volume [4]. In addition to the effects of temperature and salinity changes, other factors contribute to coral health degradation. One of these factors is ammonia, which may affect stress and cause toxicity to coral as well [5]. Water temperatures are currently increasing in what is one of the most important factors leading to coral health degradation. Moreover, there have been reports that the coral areas in Sichang Island, Chonburi Province, Thailand have been affected by ammonia concentrations exceeding the standard levels (over $0.07 \mathrm{mgN} / \mathrm{L}$ ). Because the marine ecosystems of Sichang Island are contaminated by wastewater from municipal events and cargo ships, both of which have the effect of increasing the ammonia concentrations [6][7]. In addition, current information about the effects of ammonia on the safety of invertebrates is very limited [8]. Thus, this research explores the effects of temperature and ammonia on coral health status among Acropora sp., Turbinaria $s p$. and Porites $s p$. based on evaluation of coral health status with the coral health chart[9]. Next, the acute toxicity of ammonia concentrations resulting in bleached coral at more than $50 \%$ was calculated by Probit analysis and photographic assessment was used for analysis of the active polyp percentages of Acropora $s p$. compared with health status percentages.

\section{Methodology}

\subsection{Acute effects of temperature and ammonia}

The experiments were carried at Sichang Island, Thailand, among acclimated coral species in filtered seawater ponds with continuous water flowing for 7 days before starting the experiments, which were conducted in triplicate. The selected corals sizes were between 3 and 4 $\mathrm{cm}$. These were compared with the coral health chart at Levels 5-6 where no coral bleaching was found on a piece of coral (Figure 1). The corals were then placed in glass cases with filtered seawater. These samples were aerated and temperatures were set at $30^{\circ} \mathrm{C}$ and $33^{\circ} \mathrm{C}$ with a glass heating rod. Salinity and $\mathrm{pH}$ were constantly controlled ( $30 \mathrm{ppt}, \mathrm{pH} 8)$, while the concentrations of ammonia were varied at $0,0.05,0.07$ and $0.1 \mathrm{mgN} / \mathrm{L}$., respectively. Zooxanthellae density [10], salinity, $\mathrm{pH}$ and temperature were measured and coral health status was recorded at $0,12,24$ and $48 \mathrm{hrs}$. 

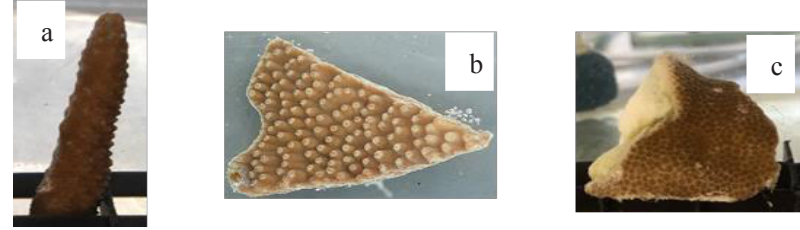

Figure 1. Coral species: a) Acropora sp. b) Turbinaria sp. c) Porites sp.

\subsection{Coral health status evaluation}

Coral health status was evaluated by using the coral health chart (Figure 2). The color determination was grouped into 4 groups and coral health statuses were classified into 6 levels [9]. A Level 6 color is representative of good health status for the coral (best health) and Level 1 color is representative of declining coral health status (worst health). After evaluating the coral health based on color the researchers calculated health condition and mortality percentages as shown in Table 1. If coral colors were lower than Level 3, the coral was identified as having a mortality percentages of more than $50 \%$..

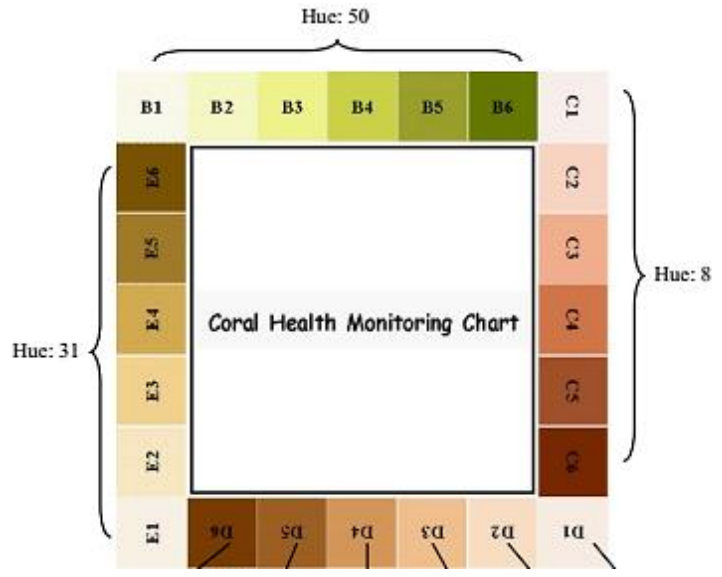

Figure 2. Coral health chart [9]

Table 1. Health status and mortality percentages from the coral health chart

\begin{tabular}{cccc}
\hline Level & Remark & $\begin{array}{c}\text { Health status } \\
\text { percentages }\end{array}$ & $\begin{array}{c}\text { Mortality } \\
\text { percentages }\end{array}$ \\
\hline 1 & Worst health & 16.67 & 83.33 \\
2 & Poor health & 33.33 & 66.67 \\
3 & Declining health & 50.00 & 50.00 \\
4 & Fair health & 66.67 & 33.33 \\
5 & Good health & 83.33 & 16.67 \\
6 & Best health & 100.00 & 0.00 \\
\hline
\end{tabular}

\subsection{Data analysis}

The researchers recorded pictures and amounts of coral with colors lower than Level 3. Next, the recorded data was converted to mortality percentages in order to calculate the lethal concentrations $\left(\mathrm{LC}_{50}\right)$ from acute toxicity testing at $48 \mathrm{hrs}$ by using Probit analysis [11]. Finally, the correlations of health status percentages and Zooxanthellae density were determined.

\subsection{Active polyp percentages}

The authors found it difficult to observe any stress in Acropora $s p$. with the naked eye. Therefore, active polyps were recorded by camera, converting true color into 256 gray scales. Fragment areas were selected and counted for active polyps (extend polyps), white spots and non-active polyps and red spots from 256 gray-scale picture [2].

Active polyp percentages were calculated at $100 *$ active polyp numbers/(total polyps counted)

\section{Results and Discussion}

\subsection{Effects of Temperature and Ammonia}

In the experiment, the health status and mortality percentages of Acropora sp., Turbinaria sp., and Porites $s p$. at ammonia concentrations of $0,0.05,0.07$ and 0.1 $\mathrm{mgN} / \mathrm{L}$ at temperatures of $30^{\circ} \mathrm{C}$ and $33^{\circ} \mathrm{C}$ as shown in Tables 2 and 3, respectively.

For Acropora sp. (branching coral type), the results at a temperature of $30^{\circ} \mathrm{C}$ and $48 \mathrm{hrs}$ indicated the coral health statuses to range from Fair to Good (color exceeding Level 3) and to be calculated at $74.07 \%$ $79.63 \%$. At $33^{\circ} \mathrm{C}$ and $48 \mathrm{hrs}$, coral health statuses ranged from Bad to Poor and could be calculated at $25.93 \%$ $48.15 \%$. At $33^{\circ} \mathrm{C}$ and $48 \mathrm{hrs}$, all conditions made coral health sensitive to increasing with mortality percentages exceeding $50 \%$ and the ability to calculate the effects of ammonia concentrations on coral bleaching or $\mathrm{LC}_{50}$ (Figure 3). The ammonia concentration of $0.1 \mathrm{mgN} / \mathrm{L}$ had the highest mortality percentages at $74.07 \%$. When the mortality percentages of the corals exceeded $50 \%, \mathrm{LC}_{50}$ could be calculated by using Probit analysis. At $33^{\circ} \mathrm{C}$, the ammonia concentrations leading to coral bleaching, or a 50 -percent coral mortality at $48 \mathrm{hrs}$ was equal to 0.043 $\mathrm{mgN} / \mathrm{L}$.

For Turbinaria sp., a plate coral type, at $30^{\circ} \mathrm{C}$ and 48 hrs, coral health statuses ranged from Fair to Good (color exceeding Level 3) and could be calculated at 68.52$79.63 \%$. At $33^{\circ} \mathrm{C}$ and $48 \mathrm{hrs}$, the coral health statuses ranged from Bad to Good and could be calculated at $36.67-75.00 \%$. At $33^{\circ} \mathrm{C}$ and $48 \mathrm{hrs}$ with ammonia concentrations of 0.07 and $0.1 \mathrm{mgN} / \mathrm{L}$, the mortality percentages of the coral health were found to increase by more than $50 \%$ and could be calculated at $\mathrm{LC}_{50}$ (Figure 4). The ammonia concentration of $0.1 \mathrm{mgN} / \mathrm{L}$ had the highest mortality percentages at $63.33 \%$. When the coral mortality exceeded $50 \%, \mathrm{LC}_{50}$ could be calculated by using Probit analysis. At $33^{\circ} \mathrm{C}$, the ammonia concentration that resulted in coral bleaching or 50percent coral mortality at $48 \mathrm{hrs}$ was equal to 0.075 $\mathrm{mgN} / \mathrm{L}$. 
Table 2. Health status and mortality percentages at $30^{\circ} \mathrm{C}$

\begin{tabular}{|c|c|c|c|c|c|}
\hline \multirow{2}{*}{$\begin{array}{l}\text { Ammonia } \\
(\mathrm{mgN} / \mathrm{L})\end{array}$} & \multicolumn{4}{|c|}{ Health status percentage } & \multirow{2}{*}{$\begin{array}{c}\text { Mortality } \\
\text { percentage }\end{array}$} \\
\hline & 0 hrs. & 12 hrs. & 24 hrs. & $48 \mathrm{hrs}$. & \\
\hline \multicolumn{6}{|l|}{$\begin{array}{c}\text { Acropora } \\
\text { sp. }\end{array}$} \\
\hline 0 & 83.33 & 83.33 & 79.63 & 79.63 & 20.37 \\
\hline 0.05 & 90.74 & 81.48 & 81.48 & 79.63 & 20.37 \\
\hline 0.07 & 88.89 & 85.18 & 81.48 & 75.93 & 24.07 \\
\hline 0.1 & 90.74 & 90.74 & 83.33 & 74.07 & 25.93 \\
\hline \multicolumn{6}{|l|}{$\begin{array}{c}\text { Turbinaria } \\
s p .\end{array}$} \\
\hline 0 & 100.00 & 85.19 & 79.63 & 79.63 & 20.37 \\
\hline 0.05 & 100.00 & 85.42 & 83.33 & 77.08 & 22.92 \\
\hline 0.07 & 100.00 & 81.48 & 79.63 & 75.93 & 24.07 \\
\hline 0.1 & 100.00 & 83.33 & 74.07 & 68.52 & 31.48 \\
\hline \multicolumn{6}{|l|}{ Porites sp. } \\
\hline 0 & 83.33 & 83.33 & 66.67 & 66.67 & 33.33 \\
\hline 0.05 & 83.33 & 83.33 & 66.67 & 63.89 & 36.11 \\
\hline 0.07 & 83.33 & 80.55 & 63.89 & 61.11 & 38.89 \\
\hline 0.1 & 83.33 & 74.99 & 58.33 & 55.55 & 44.45 \\
\hline
\end{tabular}

Table 3. Health status and mortality percentages at $33^{\circ} \mathrm{C}$.

\begin{tabular}{|c|c|c|c|c|c|}
\hline \multirow{2}{*}{$\begin{array}{c}\text { Ammonia } \\
(\mathrm{mgN} / \mathrm{L})\end{array}$} & \multicolumn{4}{|c|}{ Health status percentage } & \multirow{2}{*}{$\begin{array}{c}\text { Mortality } \\
\text { percentage }\end{array}$} \\
\hline & 0 hrs. & $12 \mathrm{hrs}$. & $24 \mathrm{hrs}$. & $48 \mathrm{hrs}$. & \\
\hline \multicolumn{6}{|l|}{$\begin{array}{c}\text { Acropora } \\
\text { sp. }\end{array}$} \\
\hline 0 & 83.33 & 59.26 & 48.89 & 48.15 & 51.85 \\
\hline 0.05 & 87.03 & 87.03 & 79.63 & 31.48 & 63.52 \\
\hline 0.07 & 85.18 & 59.26 & 53.70 & 27.78 & 72.22 \\
\hline 0.1 & 87.03 & 83.33 & 51.85 & 25.93 & 74.07 \\
\hline \multicolumn{6}{|l|}{$\begin{array}{c}\text { Turbinaria } \\
\text { sp. }\end{array}$} \\
\hline 0 & 100.00 & 80.00 & 66.67 & 63.33 & 36.67 \\
\hline 0.05 & 100.00 & 91.67 & 76.67 & 75.00 & 25.00 \\
\hline 0.07 & 100.00 & 83.33 & 54.17 & 47.62 & 52.38 \\
\hline 0.1 & 100.00 & 80.00 & 60.00 & 36.67 & 63.33 \\
\hline \multicolumn{6}{|l|}{ Porites sp. } \\
\hline 0 & 83.33 & 83.33 & 66.67 & 63.89 & 36.11 \\
\hline 0.05 & 83.33 & 80.55 & 63.89 & 52.76 & 47.23 \\
\hline 0.07 & 83.33 & 80.55 & 58.33 & 41.68 & 58.32 \\
\hline 0.1 & 83.33 & 63.89 & 55.55 & 36.10 & 63.90 \\
\hline
\end{tabular}

For Porites sp., a massive coral type, at $30^{\circ} \mathrm{C}$ and 48 hrs, coral health statuses ranged from Poor to Fair (color exceeding Level 3) and could be calculated at 55.55$66.67 \%$. At $33^{\circ} \mathrm{C}$ and $48 \mathrm{hrs}$, the coral health statuses ranged from Bad to Fair and could be calculated at 36.10$63.89 \%$. At $33^{\circ} \mathrm{C}$ and 48 hrs with ammonia concentrations of 0.07 and $0.1 \mathrm{mgN} / \mathrm{L}$, the coral health was sensitive to an increased mortality percentages exceeding $50 \%$ and $\mathrm{LC}_{50}$ could be calculated (Figure 5). The ammonia concentration of $0.1 \mathrm{mgN} / \mathrm{L}$ had the highest mortality percentages at $63.90 \%$. When the coral mortality percentages exceeded $50 \%, \mathrm{LC}_{50}$ could be calculated by using Probit analysis. At $33^{\circ} \mathrm{C}$, the ammonia concentration that had the effect of coral bleaching or $50 \%$ of corals mortality at $48 \mathrm{hrs}$ was equal to $0.054 \mathrm{mgN} / \mathrm{L}$.

According to Table $2-3$, at $30^{\circ} \mathrm{C}$ and $48 \mathrm{hrs}$, which is the normal seawater temperature, three species of corals had mortality percentages of less than $50 \%$, even if the concentrations of ammonia and the result will incapability to calculate the ammonia concentrations effect to coral bleaching or $\mathrm{LC}_{50}$. Thus, the mortality percentages will continue to increase with rising ammonia concentrations. At $33^{\circ} \mathrm{C}$ and $48 \mathrm{hrs}$, Acropora sp. had a mortality percentages exceeding $50 \%$ under all conditions, but Turbinaria sp. and Porites sp. at $33^{\circ} \mathrm{C}$ with ammonia concentrations of 0.07 and $0.1 \mathrm{mgN} / \mathrm{L}$ could also have mortality percentages exceeding $50 \%$. According to the findings, individual coral species can resist varied ammonia concentrations and calculations of $\mathrm{LC}_{50}$ for three species found Turbinaria $s p$. to be the species capable of resisting the highest varied ammonia concentrations, followed by Porites sp. and Acropora sp., respectively. The findings also indicated that the stress factor affecting coral health status was the shape of the corals. This finding is related to the Typical Surface Ocean guidelines that should be less than $0.1 \mathrm{mgN} / \mathrm{L}$ [12] and $\mathrm{LC}_{50}$ is close to the Marine Water Quality Standard for Coral reef conservation at not over $0.07 \mathrm{mgN} / \mathrm{L}$ but the $\mathrm{LC}_{50}$ of Acropora sp. and Porites sp. is less than the standard. If wastewater containing ammonia concentrations higher than $\mathrm{LC}_{50}$ is released, the corals will become bleached. Moreover, the effect of temperature is related to a [13] study finding that temperatures exceeding $30^{\circ} \mathrm{C}$ will have the effect of decreasing the Zooxanthellae density in the coral tissues, while increasing seawater temperature by approximately 1 $2^{\circ} \mathrm{C}$ will result in coral bleaching [14]. In 2010, Thailand reported the seawater temperatures on Phuket Island to be rising from normal temperatures at $29^{\circ} \mathrm{C}$ to $33.5^{\circ} \mathrm{C}$ for thirty consecutive days. The result was that some or all of the corals in that area had bleaching [15].

\subsection{Health status percentages and Zooxanthellae density}

According to the measurement of Zooxanthellae density in the experimental seawater of Acropora sp., Turbinaria sp., and Porites sp. at $33^{\circ} \mathrm{C}$ and $48 \mathrm{hrs,}$, the Zooxanthellae density was found to be correlated with coral health status at an ammonia concentration of $0.1 \mathrm{mgN} / \mathrm{L}$ where the highest Zooxanthellae densities encountered were $17.50,109.40$, and 23.17 cells $/ \mathrm{ml}$, all of which were correlated with declining coral health status as shown in Table 4.

When corals are under stressful conditions, they activate a defense mechanism caused by unstable 
conditions by using mucus secretions [16]. If the temperature and ammonia concentrations rise, the corals will accelerate the mucus secretion process, which makes the color of the corals fade because the mucus secretions make the coral tissue slip away with the effect of decreasing the amount of Zooxanthellae in coral tissues [17], which is related to Zooxanthellae density measurements in experimental seawater.

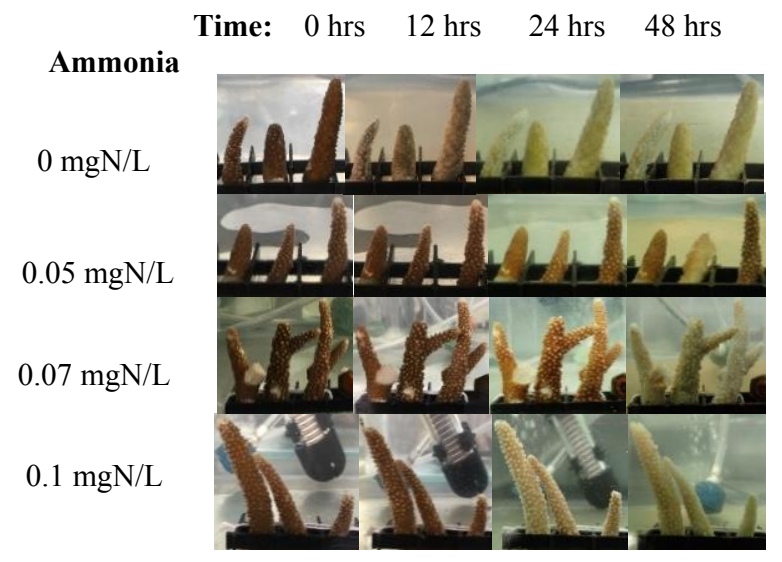

Figure 3. The effects of ammonia on Acropora sp. at $33^{\circ} \mathrm{C}$

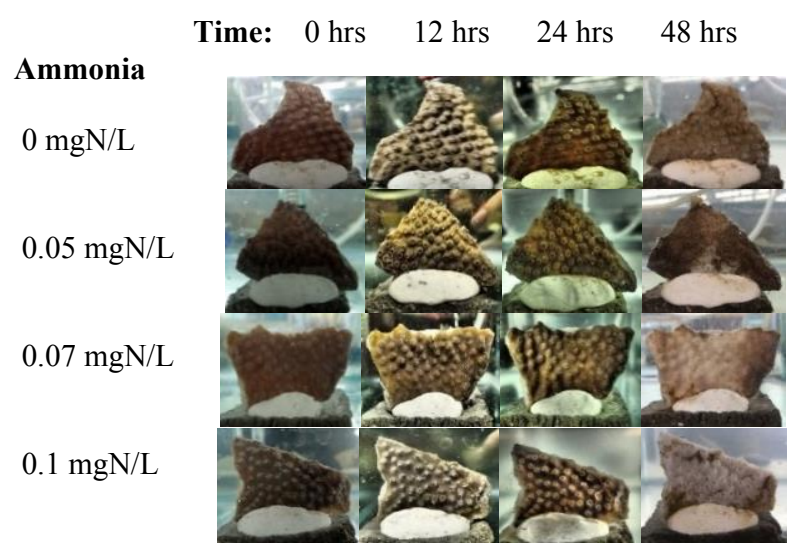

Figure 4. The effects of ammonia on Turbinaria sp. at $33^{\circ} \mathrm{C}$

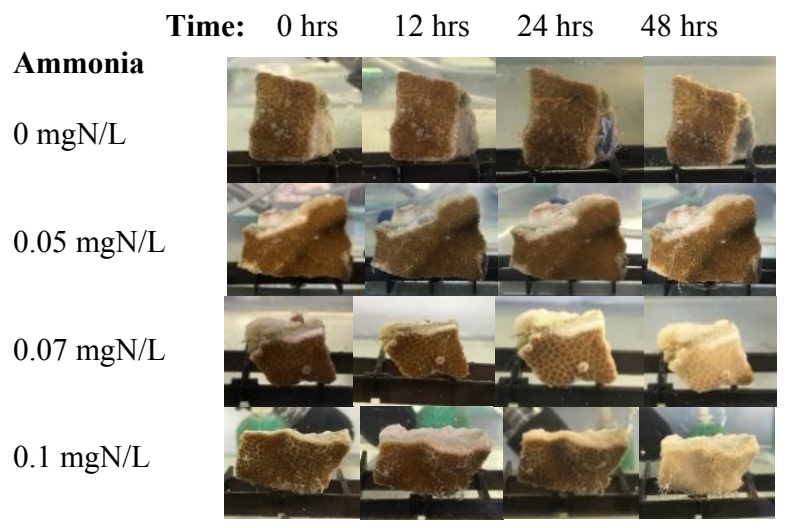

Figure 5. The effects of ammonia on Porites $s p$. at $33^{\circ} \mathrm{C}$.
Observation with the naked eye at $33^{\circ} \mathrm{C}$ and $48 \mathrm{hrs}$ with an ammonia concentration of $0.1 \mathrm{mgN} / \mathrm{L}$ found coral health status to decline. Thus, it is indicated that corals have the greatest Zooxanthellae slip-out process. Therefore, ammonia is another factor that results in coral bleaching or declining coral health [18]. According to the findings, corals at $32^{\circ} \mathrm{C}$ have the highest slip-out rate after $18 \mathrm{hrs}$ and ammonia results in more coral bleaching. Coral bleaching can recover in full or in part, depending on the cause of the bleaching, including the severity of the stress with effects causing damage inside the corals [19].

Table 4. Health status percentages and Zooxanthellae density at $33^{\circ} \mathrm{C}$ and $48 \mathrm{hrs}$

\begin{tabular}{|c|c|c|}
\hline $\begin{array}{c}\text { Ammonia conc. } \\
(\mathrm{mgN} / \mathrm{L})\end{array}$ & $\begin{array}{c}\text { Health status } \\
(\%)\end{array}$ & $\begin{array}{l}\text { Zooxanthellae density } \\
(\text { cells } / \mathrm{ml})\end{array}$ \\
\hline \multicolumn{3}{|l|}{ Acropora sp. } \\
\hline 0 & 48.15 & 7.50 \\
\hline 0.05 & 31.48 & 12.50 \\
\hline 0.07 & 27.78 & 15.83 \\
\hline 0.1 & 25.93 & 17.50 \\
\hline $\begin{array}{c}\text { Ammonia conc. } \\
(\mathrm{mgN} / \mathrm{L})\end{array}$ & $\begin{array}{c}\text { Health status } \\
(\%)\end{array}$ & $\begin{array}{l}\text { Zooxanthellae density } \\
(\text { cells } / \mathrm{ml})\end{array}$ \\
\hline \multicolumn{3}{|l|}{ Turbinaria sp. } \\
\hline 0 & 63.33 & 8.30 \\
\hline 0.05 & 75.00 & 60.00 \\
\hline 0.07 & 47.62 & 42.10 \\
\hline 0.1 & 36.67 & 109.40 \\
\hline $\begin{array}{c}\text { Ammonia conc. } \\
(\mathrm{mgN} / \mathrm{L})\end{array}$ & $\begin{array}{c}\text { Health status } \\
(\%)\end{array}$ & $\begin{array}{l}\text { Zooxanthellae density } \\
\text { (cells } / \mathrm{ml} \text { ) }\end{array}$ \\
\hline \multicolumn{3}{|l|}{ Porites sp. } \\
\hline 0 & 63.89 & 8.83 \\
\hline 0.05 & 52.76 & 9.00 \\
\hline 0.07 & 41.68 & 14.33 \\
\hline 0.1 & 36.10 & 23.17 \\
\hline
\end{tabular}

\subsection{Active polyp percentages}

For Acropora sp., a short polyp coral, other photographic assessment can be used for analysis of stress values [20]. In this study, active polyp percentages were compared to health status percentages (Table 5.). Determining the active polyp percentages involved counting polyps not exceeding the extend number or fixed area.

According to Table 5, health status percentages is correlated with the active polyp percentages. If health statuses are low, the active polyps will be high. Otherwise, the active polyps will be low when corals have their defense mechanism triggered by unstable conditions (high ammonia concentration). Therefore, these results are correlated with [2] other studies finding that corals in low salinity with have active polyp percentages at less than or equal to 0 .

According to Table 6, health status percentage is correlated with the active polyp percentage. If health 
statuses are low, the active polyps will be high. Otherwise, the active polyps will be low when corals have their defense mechanism triggered by unstable conditions (high ammonia concentration). Therefore, these results are correlated with [2] other studies finding that corals in low salinity with have active polyp percentages at less than or equal to zero.

Table 5. Active polyp percentages for Acropora $s p$.

\begin{tabular}{|c|c|c|c|}
\hline $33^{\circ} \mathrm{C}$ & \multicolumn{3}{|c|}{ Active polyps } \\
\hline $\begin{array}{c}\text { Ammonia } \\
(\mathrm{mgN} / \mathrm{L})\end{array}$ & $12 \mathrm{hrs}$. & 24 hrs. & $48 \mathrm{hrs}$. \\
\hline 0 & 13 & 11 & 10 \\
\hline 0.05 & 13 & 11 & 9 \\
\hline 0.05 & 11 & 1 & 1 \\
\hline 0.1 & 4 & 0 & 0 \\
\hline $33^{\circ} \mathrm{C}$ & \multicolumn{3}{|c|}{ Non-active polyps } \\
\hline $\begin{array}{c}\text { Ammonia } \\
(\mathrm{mgN} / \mathrm{L})\end{array}$ & $12 \mathrm{hrs}$. & $12 \mathrm{hrs}$. & 12 hrs. \\
\hline 0 & 16 & 16 & 16 \\
\hline 0.05 & 14 & 14 & 14 \\
\hline 0.05 & 44 & 44 & 44 \\
\hline 0.1 & 39 & 39 & 39 \\
\hline $33^{\circ} \mathrm{C}$ & \multicolumn{3}{|c|}{ Active polyp percentages } \\
\hline $\begin{array}{c}\text { Ammonia } \\
(\mathrm{mgN} / \mathrm{L})\end{array}$ & 12 hrs. & $12 \mathrm{hrs}$. & 12 hrs. \\
\hline 0 & 49.61 & 49.61 & 49.61 \\
\hline 0.05 & 47.08 & 47.08 & 47.08 \\
\hline 0.05 & 20.95 & 20.95 & 20.95 \\
\hline 0.1 & 8.28 & 8.28 & 8.28 \\
\hline
\end{tabular}

Table 6. Comparison of health status and active polyp percentages.

\begin{tabular}{ccc}
\hline $33^{\circ} \mathrm{C}$ & \multicolumn{2}{c}{12 hrs. } \\
\hline $\begin{array}{c}\text { Ammonia } \\
(\mathrm{mgN} / \mathrm{L})\end{array}$ & $\begin{array}{c}\text { Health Status } \\
(\%)\end{array}$ & $\begin{array}{c}\text { Active Polyps } \\
(\%)\end{array}$ \\
\hline 0 & 59.26 & 49.61 \\
0.05 & 87.03 & 47.08 \\
0.07 & 59.26 & 20.95 \\
0.1 & 83.33 & 8.28 \\
\hline $33^{\circ} \mathrm{C}$ & \multicolumn{2}{c}{24 hrs. } \\
\hline Ammonia & Health Status & Health Status \\
$(\mathrm{mgN} / \mathrm{L})$ & $(\%)$ & $(\%)$ \\
\hline 0 & 48.89 & 48.89 \\
0.05 & 79.63 & 79.63 \\
0.07 & 53.70 & 53.70 \\
0.1 & 51.85 & 51.85 \\
\hline $33^{\circ} \mathrm{C}$ & \multicolumn{3}{|}{48 hrs. } \\
\hline Ammonia & Health Status & Health Status \\
$(\mathrm{mgN} / \mathrm{L})$ & $(\%)$ & $(\%)$ \\
\hline 0 & 48.15 & 48.15 \\
0.05 & 31.48 & 31.48 \\
0.07 & 27.78 & 27.78 \\
0.1 & 25.93 & 25.93 \\
\hline \multicolumn{3}{c}{}
\end{tabular}

\section{Conclusion}

In this study, the results on the effects of temperature and ammonia on coral health status for Acropora sp., Turbinaria $s p$., and Porites $s p$. were determined by calculating acute toxicity test $\left(50 \%\right.$ Lethal Concentration: $\left.\mathrm{LC}_{50}\right)$ with Probit analysis at temperatures of $30^{\circ} \mathrm{C}$ and $33^{\circ} \mathrm{C}$ and time durations of 24 and $48 \mathrm{hrs}$ together with ammonia concentrations of $0,0.05,0.07$, and $0.1 \mathrm{mgN} / \mathrm{L}$. The results indicated that temperatures of $30^{\circ} \mathrm{C}$ and $33^{\circ} \mathrm{C}$ with ammonia concentrations will enhance the bleaching or declining of coral health status, and severity can be determined by following up on ammonia concentrations. Moreover, at $33^{\circ} \mathrm{C}$ and $48 \mathrm{hrs}$, Acropora sp. had a mortality percentages exceeding 50\% under all conditions, while Turbinaria $s p$. and Porites sp. at $33^{\circ} \mathrm{C}$ with ammonia concentrations 0.07 and $0.1 \mathrm{mgN} / \mathrm{L}$ can cause the mortality percentages to exceed $50 \%$. Thus, the findings indicate that individual coral species can resist varied ammonia concentrations and $\mathrm{LC}_{50}$ can be calculated at $48 \mathrm{hrs}$ at a temperature of $33^{\circ} \mathrm{C}$, causes corals to have bleaching or declining coral health at over 50\%. After calculating at $48 \mathrm{hrs}$ for Acropora sp., Turbinaria sp. and Porites sp. $\mathrm{LC}_{50}$ were equal to 0.043 , 0.075 , and $0.054 \mathrm{mgN} / \mathrm{L}$, respectively. On the other hand, other conditions resulting in bleaching that exceed 50\% could not be found on corals and $\mathrm{LC}_{50}$ could not be calculated. Measuring active polyp percentages is a useful method for monitoring the health status of coral under any stressful conditions. High temperatures, high ammonia concentrations, low salinity and community waste are highly threatening stress factors for shallow water coral. This study reported a correlation between health status percentages and active polyp percentages. Acropora $s p$. was successfully analyzed for stress value by using active polyp percentages. The bleaching studies in most countries continue to focus on studies limited to the physical factors such as temperature, salinity, $\mathrm{pH}$, ammonia, and nitrate. However, other factors can also result in coral bleaching. In the future, the effects of other physical factors resulting in bleaching or declining coral health should be studied as the results of this study and coral health status observation in the coastal areas will be conducive to lower ammonia concentrations than the guidelines on wastewater in the target areas. Furthermore, the data from this study can be used for coral reef management with relevant agencies such as the Department of Marine and Coastal Resources.

\section{Acknowledgements}

This research was supported by the $90^{\text {th }}$ Anniversary of Chulalongkorn University, Rachadapisek Sompote Fund academic year 2017. The authors would like to thank the staff of Sichang Marine Science Research Station, Chonburi, Thailand for their assistance and support during the experiments. The authors also would like to express their appreciation for the equipments support of the Global Environmental System Leaders Program, Keio University, Japan.

\section{References}

1. Chankong, A. Biodiversity of inververtebrate in Thailand Sea: Corals. Conference 2014 International Day for Biodiversity: Island Biodiversity, June 22-24 2014: Walailak University, Nakhonsithammarat, Thailand.

2. Rungsupa, S., Chawakitchareon, P., Hansuebsai, A., Sasaki, S., and Kiyoki, Y. Photographic Assessment of Coral Stress: Effect of Low Salinity to Acropora sp. Goniopora $s p$.and Pavona sp. at Sichang Island, 
Thailand. Information Modelling and Knowledge Bases XXIX, IOS Press, 2018, 301: 137-148.

3. Rungsupa, S., Sesulihatien, W. T., Hansuebai, A., Chawakitchareon, P., Sasaki, S., and Kiyoki, Y. The Early Step of Healthiness Detection for Coral Quality of Life at Sichang Island, Thailand. The proceedings of $5^{\text {th }}$ International Conference on Environmental Engineering, Science and Management, Environmental Engineering Association of Thailand, The Twin Towers Hotel, Bangkok, Thailand, May 11-13, 2016, (11R5-11).

4. Fitt, W. K., McFarland, F. K., Warner, M. E., and Chilcoat. G. C. Seasonal patterns of tossue biomass and densities of symbiotic dinoflagellates in reef corals and relation to coral bleaching. American Society of Limnology and Oceanography. 2000, 45: 667-685.

5. Hansuebsai, A., Rungsupa, S., Kiyoki, Y., Sasaki, S., and Chawakitchareon, P. Study the effect of Ammonia by Image Analysis on Healthiness Detection for Coral Quality of Life. Information Modelling and Knowledge Bases XXIX, IOS Press, 2018, 301: 343-353.

6. Regional Environment Office. Reports from the environmental quality situation in Eastern of Thailand at 2015. Regional Environment Office 13 (Chonburi). 2016, 106 p.

7. Coverdale, T. C., Herrmann, N. C. Altieri A. H., and Bertness, M. D. Latent impacts: the role of historical human activitiy in coastal habitat loss. Frontiers in Ecology and Environment, January 2013, 69-74.

8. Lawson, T. B. Fundamentals of aquaculture engineering. Chapman \& Hall, New York. 1995, pp. 355.

9. Siebeck, U. E., Marshall, N. J., Klü, A., and HoeghGuldberg, O. Monitoring coral bleaching using a colour reference card. Coral Reefs. 2006, 25 (3): 453-460.

10. Lenore, S. C., Arnold, E. G., and Andrew, D. E. Standard Methods for the Examination of Water and Wastewater $22^{\text {nd }}$ Edition, 10200-Plankton. 2012, pp. 1992-2019.

11. Finney, D. J. Probit Analysis ( $2^{\text {nd }}$ Ed). Journal of the Institute of Actuaries. 1952, 78 (3): 388-390.
12. Nordin, R. N., and Pommen, L. W. Water Quality Guidelines for Nitrogen (Nitrate, Nitrite, and Ammonia) Overview Report Update Water Stewardship Division, Ministry of Environment, Province of British Columbia. 2009, 28 p.

13. Nozawa, Y. Annual variation in the timing of coral spawning in a high-latitude environment: influence of temperature. The Biological Bulletin. 2012, 222 (3): 192-202.

14. Buchheim, J. Coral Reef Bleaching. Odyssey Expeditions-Marine Biology Learning Center Publications. Retrieved from http://www.marinebiology.org/coralbleaching.htm, 2016.

15. Department of Marine and Coastal Resources. Coral bleaching. Retrieved from http://marinegiscenter. dmcr.go.th/km/coral-blenching/\#.WS55qmiGPIV, 2013.

16. Kellogg, C. Coral Mucus Goes Mainstream-New Discoveries in Microbial Communities. Journal Marine Ecology Progress Series, 2004. 273: 81-88.

17. Kerswell, P. A., and Jones, J. R. Effects of hypoosmosis on the coral Stylophora pistillata: nature and cause of low salinity. Marine Ecology Progress Series. 2003, 253: 145-154.

18. Baohua, Z., Guangce, W., Bo, H., and Tseng, C. K. Effects of temperature, hypoxia, ammonia and nitrate on the bleaching among three coral species. Chinese Science Bulletin. 2004, 49 (18): 1923-1928.

19. Arthur, R., Done, T. J., Marsh, H., and Harriott, V. Local processes strongly influence post-bleaching benthic recovery in the Lakshadweep Island. Coral Reefs. 2006, 25: 427-440.

20. Winters, G., Holzman, R., Blekman, A., Beer, S., and Loya, Y. Photographic assessment of coral chlorophyll contents: Implications for ecophysiological studies and coral monitoring. Journal of Experimental Marine Biology and Ecology. 2009, 25-35. 